\title{
The Theoretical Model of an Inclusive Library for People with Disabilities and its Practical Implementation
}

\author{
Kristina Kulikauskiene* \\ Šiauliai University, P. Višinskio str. 25, LT-76351, Šiauliai, Lithuania \\ kristinakulikauskiene@gmail.com \\ Laima Liukinevičienè \\ Šiauliai University, P. Višinskio str. 25, LT-76351, Šiauliai, Lithuania \\ liukinevicienelaima@gmail.com
}

\begin{abstract}
:
Purpose and Originality: This study aims to analyse the concept of an inclusive and socially responsible library, to develop the theoretical model of an inclusive library for people with disabilities, and to investigate the practical possibilities for implementing this model in regional libraries in order to reduce social exclusion of people with disabilities and to increase their social inclusion. The paper presents the results of empirical research conducted in two counties of Lithuania. Based on the results of the interviews of heads of libraries and heads of organizations representing people with disabilities, the model of an inclusive library was supplemented and the change management of an inclusive library was actualized.

Method: The methods of this study are based on stakeholder theory (Dangi \& Gribb, 2018, pp. 339341; Harrison, Freeman \& Abreu, 2015, pp. 859-860; Lipiński \& Jamro, 2018, p. 225), where the management of stakeholders involves meeting their needs and ensuring their wellbeing. The theoretical part of the research uses the methods of scientific literature analysis, generalization, and systematization, which enabled to theoretically define the concept of an inclusive public library for people with disabilities, substantiate the instrument of the empirical research, and discuss the results of the empirical research. In the empirical part, a qualitative method of e-mail interviews was chosen to conduct the opinion survey of organizations representing people with disabilities and heads of libraries. The obtained results were analysed, then the theoretical model of an inclusive library was supplemented with practical insights of the empirical research.

Results: The results of the research showed that a changing public attitude towards public services and their accessibility (expectation is greater accessibility and diversity) stipulates the change in the roles of budget-based libraries and preconditions the development of an inclusive library for people with disabilities. Based on the theoretical and empirical findings obtained during the research, the model of an inclusive library for people with disabilities was developed and substantiated. Also, it was proved that the development of an inclusive library for people with disabilities requires the change management which involves stakeholders, i.e. representatives of people with disabilities and institutions implementing public policy at the national and local level, into all stages of the transformation process to become an inclusive organization for people with disabilities.

Society: This study highlights the need to increase the social inclusion of libraries to meet the needs of all stakeholders, including people with disabilities. Increasing the social inclusion of libraries can reduce the social exclusion of people with disabilities and promote their inclusion in the community and society
\end{abstract}

* Korespondenčni avtor / Correspondence author

Prejeto: 3. oktober 2020; revidirano: 25. november 2020; sprejeto: 26. november 2020. /

Received: 3rd October 2020; revised: 25th November 2020; accepted: 26th November 2020. 
in broad terms. An inclusive library creates added value for society and contributes to the implementation of social justice.

Limitations / further research: The empirical research was conducted in two counties of Lithuania (Šiauliai and Telšiai), involving 10 libraries. Because budget-based libraries in Lithuania have a similar management structure, operate on the grounds of the same strategic documents of the Republic of Lithuania, have similar opportunities provided by the Government and the Ministry of Culture to engage in innovative activities and address social problems, the results of the empirical research can be applied at the national level, except for the capital region, which should be investigated separately due to the high concentration of specialized libraries and the National Library. It would also be useful to analyse the best practices of other European countries whose libraries have made the largest progress in promoting social inclusion.

Keywords: social inclusion, the model of an inclusive library for people with disabilities, library services for people with disabilities.

\section{Introduction}

Today's society expects libraries to have greater access to information resources, cultural and educational activities, opportunities for lifelong learning, and the reduction of social exclusion. The changing societal expectations influence the changing role of libraries - libraries become centres of lifelong learning and socialization. The changing role of libraries is a relevant topic for research and has been studied by such authors as Appleton, Hall, Duff \& Raeside (2018, pp. 276277), Casselden, Pickard \& McLeod (2015, p. 188), Delaney \& Bates (2015, pp. 30-31), Johnson (2012, pp. 53-54), Pressley (2017, pp. 62-63), Strover (2019, p. 190 ), Subramaniam, Kodama \& Oxley (2013, pp. 1-2 ), Wyatt, Mcquire \& Butt (2018, pp. 2935-2936), Y1lmaz \& Cevher (2015, pp. 336-337), in Lithuania - Juchnevič (2016a, pp. 96-98; 2016b, pp. 159-160) and Pečeliūnaitè (2017, p. 37). Changing requirements oblige libraries to meet the needs of the society and all stakeholders and to contribute to the inclusion of people with disabilities. The services for people with disabilities is not a new area for libraries, but the changing needs of society require a new approach to this group of stakeholders and the appropriate development of services. The significance of social inclusion and libraries as socially inclusive organizations has been analysed by Irwin \& Silk (2019, pp. 1-2), Koller, Pouesard \& Rummens (2018, pp. 1-2), Kulikauskienė (2019, pp. 73-74), Lloyd (2019, pp. 51-52), Racelis (2018, pp. 2-3), who emphasised that socially inclusive libraries also focus on the needs of stakeholders and society at large. Therefore, library services must be accessible to all individuals, regardless of age, gender, race or disability. People with disabilities have the same rights as other citizens to participate in community life, activities, and events. However, these rights are often not guaranteed to people with disabilities, therefore, they experience social exclusion (Ruškus, 2002, pp. 47-48). Libraries have an extensive network of institutions, a wide range of services and serve individuals of all ages and social groups. In this way, they can act as social justice operators and provide all members of society with access to information resources, and enable them to participate in educational and cultural activities. Libraries have a unique opportunity to reduce social exclusion by becoming inclusive, open and accessible to all people (Kaeding, 2015, p. 13). 
However, despite positive changes in library infrastructure, people with disabilities often face negative public attitudes, inadequate infrastructure, and a lack of specialized equipment and services. This problem is particularly pronounced in smaller towns and villages in Lithuania, where libraries are often not adapted for people with disabilities and a variety of services does not accommodate their needs. This situation can be improved by increasing the role and responsibility of libraries in social inclusion and by expanding a range of services for people with disabilities. Therefore, the problem of the research is how to implement practically these scientific insights and government recommendations for libraries to become socially inclusive?

The scientific problem analysed in this paper can be presented by the following questions: What are the main features of an inclusive library?, What model of a socially inclusive library for people with disabilities is provided by science today?, and What are the possibilities for putting this model into practice? The aim of the research is having conceptualized an inclusive and socially responsible library, to develop the theoretical model of an inclusive library for people with disabilities and to investigate the practical possibilities of its implementation in Lithuanian regional libraries. The objectives of the research: 1) Having analysed the scientific literature on the changing role of libraries and the development of an inclusive organization, to define the concept of the library as a socially responsible and inclusive organization and to improve the theoretical model of an inclusive library for people with disabilities; 2) Based on the empirical research data, to substantiate the practical applicability of the model of an inclusive library for people with disabilities in Lithuanian libraries.

\section{Theoretical framework}

In the 21 st century, the role of libraries is changing - from book lending to community centres with a wide range of goals: teaching of digital literacy, organizing lifelong learning, conducting cultural, informational and educational activities, and reducing social exclusion (Appleton, Hall, Duff \& Raeside, 2018, p. 276; Johnson, 2012, p. 54; Pečeliūnaitė, 2017, pp. 37-38; Y1lmaz \& Cevher, 2015 p. 336). Today, there is a direct connection between the library and society, due to the inseparable nature of its social functions and meeting the needs of society (Juchnevič, $2016 \mathrm{pp}$. 34-35). The library community consists of the users who differ in their social status, education, mentality, therefore, public libraries' aspiration to be accessible to every member of the community (Pečeliūnaité, 2017, p. 38) and public pressure on libraries to increase the accessibility of their services affect libraries' activities and roles. The scientific literature identifies the following key roles of the library: informational, educational-cultural, communal, and social.

The informational role means that the library can ensure the access to literature and high-quality information (e.g. books, periodicals, Internet access) and provide services to all social groups (Appleton, Hall, Duff \& Raeside, 2018, p. 276; Davey, 2013, p. 4; Kijauskaitè \& Alèbaitè, 2016, p. 7;). The educational-cultural role means that the library can offer opportunities for cultural 
leisure (Kijauskaite \& Alèbaitė, 2016, p. 8; Wyatt, Mcquire \& Butt, 2018, pp. 2935-2936; Y1lmaz \& Cevher, 2015, p. 338;), which today is associated with educational and lifelong learning activities. By providing non-formal learning services or organizing non-formal learning activities, libraries train users in information and economic literacy, creativity, foreign languages, etc. This training also develops general competencies that help adapt to the labour market and social life. The communal role means that the library is perceived as a space for communication and community building (Davey, 2013, p. 4; Kijauskaite \& Alëbaitè, 2016, p. 7; Sung, Hepworth \& Ragsdell, 2012, pp. 206-207). Today, the effectiveness of the library depends on its cooperation with communities, educational and scientific institutions, non-governmental organizations, cultural, professional and amateur arts organizations, etc., because the library is an accessible place for everybody to create joint projects and communicate. The communal role is closely intertwined with the social role of the library as a space for social interaction. According to this concept, the library is understood as an open space where individuals can realize their ideas through communication, learning, leisure, work, etc. This is of particular relevance for stigmatized and socially excluded groups and their inclusion in social life (Juchnevič, 2016, p. 35). Libraries become the promoters of social justice, by providing everyone with information resources and enabling them to participate in educational and cultural activities (Moisey, 2007, pp. 56-57).

According to Juchnevič (2016, p. 35) and Reid (2019, pp. 2-3), by providing free of charge services and access to modern technologies, libraries provide an opportunity to learn about culture, participate in lifelong learning, are open to various social groups. According to authors, it can be stated that the social role of the library involves all previously mentioned roles and integrates them into a whole - in today's world, libraries through social interaction with individuals, informal communities, institutions, through the involvement into strategic state processes (promotion of lifelong learning, implementation and development of innovations, development of science potential, etc.) become the organizations reducing social exclusion and increasing socialization. Even in the smallest towns and villages, libraries working with people of all ages, become strategically important organizations for implementing social policies, as other public organizations (schools, cultural centres, day-care centres, etc.) do not have such a wide network of organizations and such diversity. Libraries contribute to the reduction of information, digital and social exclusion by providing access to information resources, free internet, by organizing free of charge events and educational activities.

The changing roles of the library precondition the organizational change - to become an inclusive organization that meets not only users' needs but also the growing needs of society. Having the access to the latest information resources, being equipped with the new technologies, libraries can develop the dissemination of innovative products and services, ensure their accessibility to all citizens, anticipate future public needs and prepare for them, and participate in international, national, and inter-organizational projects. 
The concept of a socially inclusive organization is inseparable from the concept of a socially responsible organization. Public sector institutions take responsibility for creating the public wellbeing through the services they provide (Racelis, 2018, p. 2). For libraries, social responsibility and inclusion are, first of all, meeting the needs of stakeholders. According to Racelis (2018, p. 3), the social responsibility of the library comprises four levels: 1) The responsibility for information resources and books stored in the library; 2) The responsibility for the library staff; 3) The responsibility for library users; 4) The responsibility for the society in general. According to this approach, the responsibility of the library transcends the boundaries of an individual organization, therefore, the availability of service becomes an important criterion for developing an inclusive organization.

Therefore, it is possible to state that an inclusive library performs its informational, educational, cultural, communal, and social functions in a socially responsible manner, whose services are accessible to members of diverse communities, which takes care about its employees' wellbeing, development of their competencies, meets consumers' needs, and brings together all individuals, communities, and organizations for joint activities. Such library provides added value to society through social justice and promotes people from socially excluded groups to socialize. The activities of inclusive libraries are in line with the provisions of global and national legal documents to ensure equal opportunities and accessibility; their strategic and key operational documents usually foresee the mission and change of social inclusion. An inclusive library cooperates with a variety of organizations, local communities and publicises information about its services. However, unlike other inclusive public organizations, the concept of inclusive libraries focuses on the diversity of stakeholders, and this suggests the need to constantly research their needs and expectations. The users of library services are of different age groups and come from different social groups: pre-schoolers and their parents, schoolchildren, students, employed persons, unemployed persons, retired persons, persons with various disabilities, etc. Aiming to research and respond to a variety of needs, the collaboration with other organizations that involve learning, employment, and socialization as well as with the organizations and local communities representing and integrating people experiencing social exclusion, becomes significant.

Another aspect is that inclusive libraries need to take into consideration a variety and quality of the services they provide, in order to meet the needs of society, and this requires continuous development of staff competencies. Traditional services and services that enhance socialization and employment today require a range of competencies, including competencies to work with people with disabilities (physical, mental, sensory), people with developmental disorders and to use digital technologies that increase access to library services.

According to Kaunda \& Chizwina (2019, pp. 8-9), the main factors promoting people with disabilities to use library services are accessibility of services, qualification of staff, adaptation of 
library environment, material base, equipment and services. Kowalsky \& Woodruff (2017, pp. 412), Young (2018, pp. 131-132) underlines that the library, which seeks to serve users with disabilities, has to take care of the universal design, annually review lists of activities, evaluate outcomes of inclusion, facilities and equipment designed for people with disabilities, plan new activities and staff training.

In discussions about libraries that increase the socialization of people with disabilities, researchers have proposed theoretical models of such libraries. Gibson (2006, p. 61) presented a library service model that identifies four key aspects: 1) Compliance of the documents governing the rights of people with disabilities to access to informational, cultural and educational activities with library documents; 2) Adaptation of infrastructure and equipment for people with disabilities, use of assistive technologies; 3) Specific services for people with disabilities; 4) Staff training. Kaeding (2015, p. 21), Kaeding, Velasquez \& Price (2017, p. 13) proposed the model of an inclusive library for people with disabilities that highlights seven essential components: governance, programs, physical barriers, training, partnership, marketing, and adapted information resources. All components are interconnected and include activities that make library services and the environment more attractive to people with disabilities.

In the model proposed by Kaeding (2015, pp. 21-23), Kaeding, Velasquez \& Price (2017, pp. $13-$ 17), the component 'governance' involves the management's approach to the development of the library as an inclusive organization and the inclusion of activities for people with disabilities in the library's plans, as well as the consistency of these plans with national documents. The component 'programs' lists the activities and training that libraries offer to people with disabilities. The component 'physical barriers' includes the accessibility of the library's infrastructure and facilities with the necessary specialized equipment for people with disabilities. The component 'training' includes library staff training in providing services for people with disabilities. The component 'partnership' emphasizes the cooperation of libraries with various organizations and communities of people with disabilities. The component 'marketing' emphasizes the publicity of library services for people with disabilities. The component 'information resources' includes specialized literature resources that are adapted for people with disabilities (e.g. audiobooks, Braille books).

According to the model of an inclusive library for people with disabilities proposed by Gibson (2006, p. 61), Kaeding (2015, p. 21), Kaeding, Velasquez \& Price (2017, p. 13) and taking into consideration the factors related to the enhancement of social inclusion of libraries (planning and implementation of activities for people with disabilities, assessment of achieved results), defined by Kaunda \& Chizwina (2019, pp. 8-9), Kowalsky \& Woodruff (2017, pp. 4-12), Young (2018, pp. 131-132) the following key components can be distinguished: organizational management, adaptation of environment (adapting infrastructure and equipment to ensure accessibility of services), services that meet the needs of people with disabilities (efficient service for people with 
disabilities, adaptation of information resources, cultural, educational and information services), improvement of staff competencies, cooperation (with organizations for people with disabilities, care-homes, special schools, non-governmental organizations, etc.), and publicity of services. Based on this generalization, the theoretical model of an inclusive library for people with disabilities is presented in Figure 2.1.

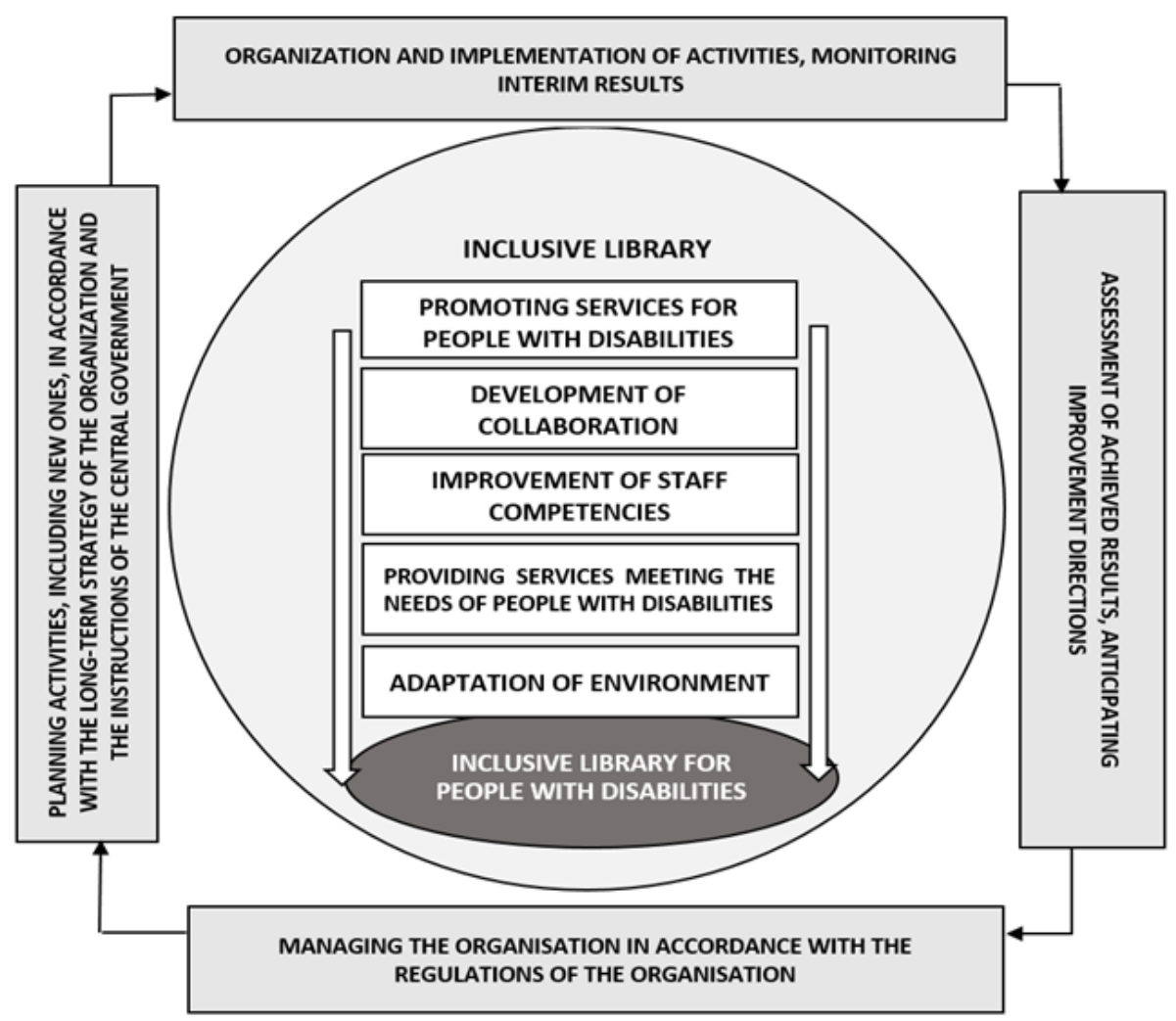

Figure 2.1. Theoretical model of an inclusive library for people with disabilities. Adapted from: Improving the Quality of Library Services for Students with Disabilities (p. 61) by A. Gibson, 2006, Westport, CT: Libraries Unlimited; "Public Libraries and Access for Children with Disabilities and Their Families: A Proposed Inclusive Library Model", by J. Kaeding, D. L, Velasquez and D. Price, 2017, Journal of the Australian Library and Information Association, 66, p. 13.

In the theoretical model of an inclusive library for people with disabilities, six components are significant for increasing the inclusion of people with disabilities. Management of an organization is a key component that enables the development of other components. Orientation towards the inclusion and improvement of services for people with disabilities should be reflected in libraries' strategic and other documents, thus forming a new organizational culture and developing new traditions. By researching, maintaining and strategizing organizational behaviour, libraries can influence the communities they work with (Koller, Pouesard \& Rummens, 2018, p. 2). It includes the change management needed to become an inclusive organization, as well as long-term and short-term plans to create a barrier-free library environment. An inclusive organization can be created by involving activities in strategic plans and other documents, making inclusion as one of 
the organization's goals, securing employees' support and development of their competencies, organizing and implementing the planned activities, monitoring the interim results, evaluating the achieved results, and anticipating opportunities for improvement (Bhatt, 2017, pp. 34-35; Butt, Nawab \& Zahid, 2018, pp. 77-79; Jalagat, 2015, pp. 1234-1235; Kennett-Hensel \& Payne, 2018, pp. 26-27;).

Through the adaptation of the environment, which includes adapting infrastructure and equipment to the needs of people with disabilities, the accessibility can be understood as reducing disparities between the disabled and non-disabled users to provide equally accessible library environment and services (Kowalsky \& Woodruff, 2017, pp. 5-6). Libraries need to put much effort to identify the needs of people with disabilities and develop services and spaces for them. Universal design is important in this area, and its principles must respond to both the library infrastructure and services. Universal design or inclusive design means that the library's material base and a range of services are oriented towards all people, both young and old, disabled and non-disabled (Koller, Pouesard \& Rummens, 2018, p. 2). In line with universal design principles, library facilities and buildings should be designed to be accessible to all users, including people with disabilities, children and the elderly (Pionke, 2017, p. 50). These principles also apply to assistive technologies increasing access to information and services (Kaunda \& Chizwina, 2019, p. 8).

The services meeting the needs of people with disabilities include the effective provision of services, the adaptation of cultural, educational and information services to people with disabilities. Libraries should make an effort to provide quality service: library staff should be prepared to serve people with different disabilities (physical, mental, visual, hearing) and people with developmental disorders. It is imperative to have a collection of information resources and a range of services accessible to all people regardless of disability (Kaunda \& Chizwina, 2019, p. 12). For people with disabilities, libraries can provide informational (e.g. to lend books, provide free internet access, organize educational events, training, etc.), educational (e.g. to organize educational, artistic, therapeutic events), and cultural (e.g. to organize exhibitions of works of people with disabilities, meetings with writers, famous people, etc.) services. It should be noted that the principles of universal design apply not only to the infrastructure of buildings but also to services that must be accessible to everyone and their content must meet the needs of different people (Pionke, 2017, p. 55). In addition to services, library inclusion can be measured by the availability of information resources to all users. Access to information resources can be ensured through assistive technology. The most commonly used aids in libraries include Braille books, audiobooks, computers with special software. The users unable to enter the library should receive books at home, to use electronic library resources, and adapted library website Information resources accessible online enable users to access them independently with specially adapted computer software (Chaputula \& Mapulanga, 2017, pp. 2-3). It gives users satisfaction because they have direct and independent access to information (Koh, 2019, p. 33). In this area, organizing 
the conferences, meetings with prominent people with disabilities, training of the public on the peculiarities of disability, etc. in libraries is significant (Kaeding, 2015, p. 54; Kaeding, Velasquez \& Price, 2017, pp. 16-17; Poinke, 2017, pp. 5-55).

Staff training includes the development of staff competencies to work with people with disabilities, both in terms of service and knowledge. This component is closely linked to the services for people with disabilities, as only qualified staff can ensure the quality service meeting the needs of people with disabilities. According to Pionke (2017, p. 49), staff training is a significant component of an inclusive library.

The development of collaboration includes cooperation with organizations for people with disabilities, care institutions, centres for social services, special schools, etc. These social partners can ensure the necessary number of program participants and can contribute to librarians' training. Collaboration with partners is essential to increase the library's social inclusion (Adkins \& Bushman, 2015, pp. 30-31).

The promotion of services is important in informing people with disabilities and their representatives about library services for them. Very often, people with disabilities do not know what libraries can offer them. Libraries should actively promote services oriented to people with disabilities (Pionke, 2017, pp. 53-54). In addition to publicizing services through various communication channels (Internet, TV, press, etc.), libraries can organize open days for people with disabilities and their representatives to visit and learn about their facilities, information resources, and various activities (Adkins \& Bushman, 2015, p. 31; Kaeding, 2015, p. 54; Kaeding, Velasquez \& Price, 2017, pp. 16-17;).

All components presented in the model are linked by the social purpose of the library, i.e. to increase the accessibility of services. Focusing on people with disabilities, the specificity of access to all these services is highlighted. Moisey (2007, pp. 57-58) and Vimarlund \& Manzoor (2017, pp. 20-22) identified main barriers to the accessibility of libraries and their services: Staff qualification (librarians may not know how to ensure accessibility of services); Infrastructure and services (library buildings and facilities may not be properly adapted, there may be no necessary information resources, people with disabilities may not know what services libraries offer them); Libraries may not have the necessary equipment; Library websites may not be suitable for people with disabilities; Libraries may not have the literature and information resources (e.g. Braille books, audiobooks, e-books). These barriers can be overcome by improving library infrastructure, services, purchasing software and information resources, and by upgrading staff qualifications.

In conclusion, libraries have all possibilities to become inclusive organizations for people with disabilities as well as socially responsible organizations by improving management, periodically 
examining the compliance of environment and services with the needs of people with disabilities, developing staff competencies and cooperation with organizations representing people with disabilities, and actively promoting services for people with disabilities.

\section{Method}

The methods of this study are based on stakeholder theory (Dangi \& Gribb, 2018, pp. 339-341; Harrison, Freeman \& Abreu, 2015, pp. 859-860; Lipiński \& Jamro, 2018, p. 225), where the management of stakeholders involves meeting their needs and ensuring their wellbeing. A qualitative research method was employed in the research. The qualitative analysis of the latest scientific sources allowed highlighting the tasks which the library has to implement in the context of social policy, discerning the features inherent to an inclusive library, summarizing the researchers' insights on the increasing the socialization of people with disabilities in order to create a theoretical model of an inclusive library for people with disabilities. The empirical research aimed to gain a deeper insight into the situation of libraries in the counties of Lithuania, i.e. the access to services for people with disabilities, and to investigate the feasibility of a theoretical model of an inclusive library.

The method. To investigate the opinion of the heads of organizations and heads of libraries on the services provided for people with disabilities in Šiauliai and Telšiai counties, a structured interview method was used for data collection. Instead of face-to-face interviews, email interviews (based on Lokman's (2006, pp. 1284-1286) and Hawkins' (2018, pp. 494-495) insights were chosen because of a wide geographic scope of the investigation and the large number of interviewees (10 heads of libraries and 15 heads of organizations for people with disabilities). This reduced the cost of the investigation and facilitated the transcription of interviews. The methods of grouping, interpretation, and generalization were used for the analysis.

Instrument of the research. The questionnaire sent to heads of organizations representing people with disabilities consisted of 32 open-ended questions structured according to the key elements of a theoretical model of an inclusive library with a focus on the development of services for people with disabilities. The questionnaire sent to heads of libraries was based of the problematic aspects identified by the representatives of people with disabilities and consisted of 24 open-ended questions related to increasing the socialization of people with disabilities through library services.

Reliability and validity of the method, the model of measuring instrument and data. The validity of the research instrument was based on the conceptual theoretical insights about an inclusive library for people with disabilities. These insights presented in the works by Gibson (2006 p. 61), Kaeding (2015, p. 21;), Young (2018, p. 131), Kaunda \& Chizwina (2019, p. 8) is the basis for the empirical research instruments. The research methodology is in line with the requirements for structured qualitative interviews (questionnaires consisted of open-ended, fixed-order questions) 
and ethical norms (Lokman, 2006, p. 1285). Conformity of the instrument questions to be implemented in practice was based on the consultation with the heads of libraries and organizations for people with disabilities by involving them in the pilot research. Before the research, the questionnaire in written form was reviewed by a team of researchers at the Institute of Regional Development of Šiauliai University. The reliability of the research material based on the questionnaire in written form is also substantiated with interviewees' interest in the research: its results are needed to further investigate the activities related to the integration of people with disabilities. Public presentation of research results is another way to ensure the reliability of the results.

The sample. A total of 25 interviewees from Šiauliai and Telšiai counties took part in the research: 15 heads of organizations representing people with disabilities (associations for people with disabilities, care homes, day-care centres, special schools), that involve persons with different disabilities (physical, hearing, visual, mental, etc.) and of different age groups (children and youth, adults and seniors) as well as 10 heads of municipal public libraries.

Research organizing. The research was conducted from September to November 2019. Out of 55 organizations representing people with disabilities in Šiauliai and Telšiai counties, 15 organizations responded to the request to participate in the survey. Out of 11 municipal public libraries, 10 heads of libraries agreed to participate in the research. The comprehensive questionnaires were sent to interviewees who agreed to participate in the research.

Research ethics. The information provided by the research participants was kept secure and confidential. Following the requirements for data protection, the interviewees were not requested to provide any additional personal data. It should be noted that participation in the research was voluntary, the purpose of the research, the research promoter and the intended use of the research results were introduced to all interviewees.

Analysis of the results. Analysing the research data, the groups of data reflecting the essential components of the model of an inclusive library for people with disabilities were analysed. They can be treated as theoretical constructs enabling to evaluate the phenomenon under research, conduct a qualitative analysis of the situation, and determine the practical implementation of the theoretical model of an inclusive library for people with disabilities.

\section{Results}

\subsection{Supplemented theoretical model of an inclusive library for people with disabilities}

The analysis of the material collected during the empirical study shows that: 1) The necessity of all processes and activities highlighted in the theoretical model of an inclusive library for people 
with disabilities has been confirmed; 2) Other activities that are currently important for the Lithuanian libraries to achieve greater socialization of people with disabilities have been revealed (e.g. public education on the socialization of people with disabilities, project activities); 3) The need for political support for the socialization of people with disabilities through libraries at the national and local level was actualized.

These findings allowed supplementing the theoretical model of an inclusive library with aspects, which can be applied practically. An essential component of the model of an inclusive library is organizational management, which based on the analysis of research data, is actualized as the change management within the organization. Interviewees outlined the things that, on the one hand, show the extensive work of libraries in involving people with disabilities (employment of people with disabilities is increased, adapted spaces are created, facilities are purchased, there is collaboration on library events, information is presented online, etc.), on the other hand, they indicated that libraries lack content awareness, consistency, managerial access, awareness that this is not another library function, and that this change affects the entire organization.

Considering a change as a planned process and transformation (Ballantyne, 2018, p. 333; Bold, 2011, p. 873; Lawrence, 2015, p. 233; etc.) necessary for organizational development (Talmaciu, 2014, p. 78), we discern in the interviewees' statements the lack of change management in the development of an inclusive library. The interviewees' statements reflecting the present situation show efforts and reasons and the lack of their implementation ("people with disabilities are invited to ongoing projects", "exhibitions of works by people with disabilities are often held", "infrastructure is insufficiently adapted due to limited funding", "there is a lack of special equipment", "research on users' opinion about services, without specifically addressing the needs of people with disabilities, is conducted", "competencies in working with people with disabilities are insufficient", etc.), and the indicated expectations highlight the need for a systemic change ("collaboration could be developed through joint projects", "we could advise libraries about training for us and choosing a topic", "social workers could certainly contribute more in creating educational programs", "training could be broadcast online", "it would be useful to get information to the society's email", "a separate access for people with disabilities on the library portal would be necessary", etc.). The need for integrated access in the development of an inclusive library for people with disabilities is also evidenced by differences in the knowledge of library activities between heads of libraries and heads of organizations for people with disabilities.

Interviewees did not outline that the development of an inclusive library for people with disabilities would have become as one of the organisation's goals, that in the management of this process, starting with initiation, stakeholders would have been involved, and, as it is known, a change requires vision, a deeper analysis of situation, operational consistency, leadership, regular communication, etc. According to researchers, change management involves a lot of management components (Butt, Nawab \& Zahid, 2018, p. 82), because it requires a lot of novelty and initiative; 
people, i.e. the implementers of change and the ones who receive benefit, are the main components; the created benefit can also affect the external environment (Bold, 2011, p. 872). Involving people with disabilities in the change management becomes important in developing an inclusive library.

On the basis of the empirical research, we improved the presented above model of an inclusive library for people with disabilities (see Figure 2.1), and designed the model of practical applicability (see Figure 4.1). It should be emphasized that in the strategically planned change from its initiation to consolidation, it is important to involve social stakeholders, especially people with disabilities, to ensure the continuation of activities.

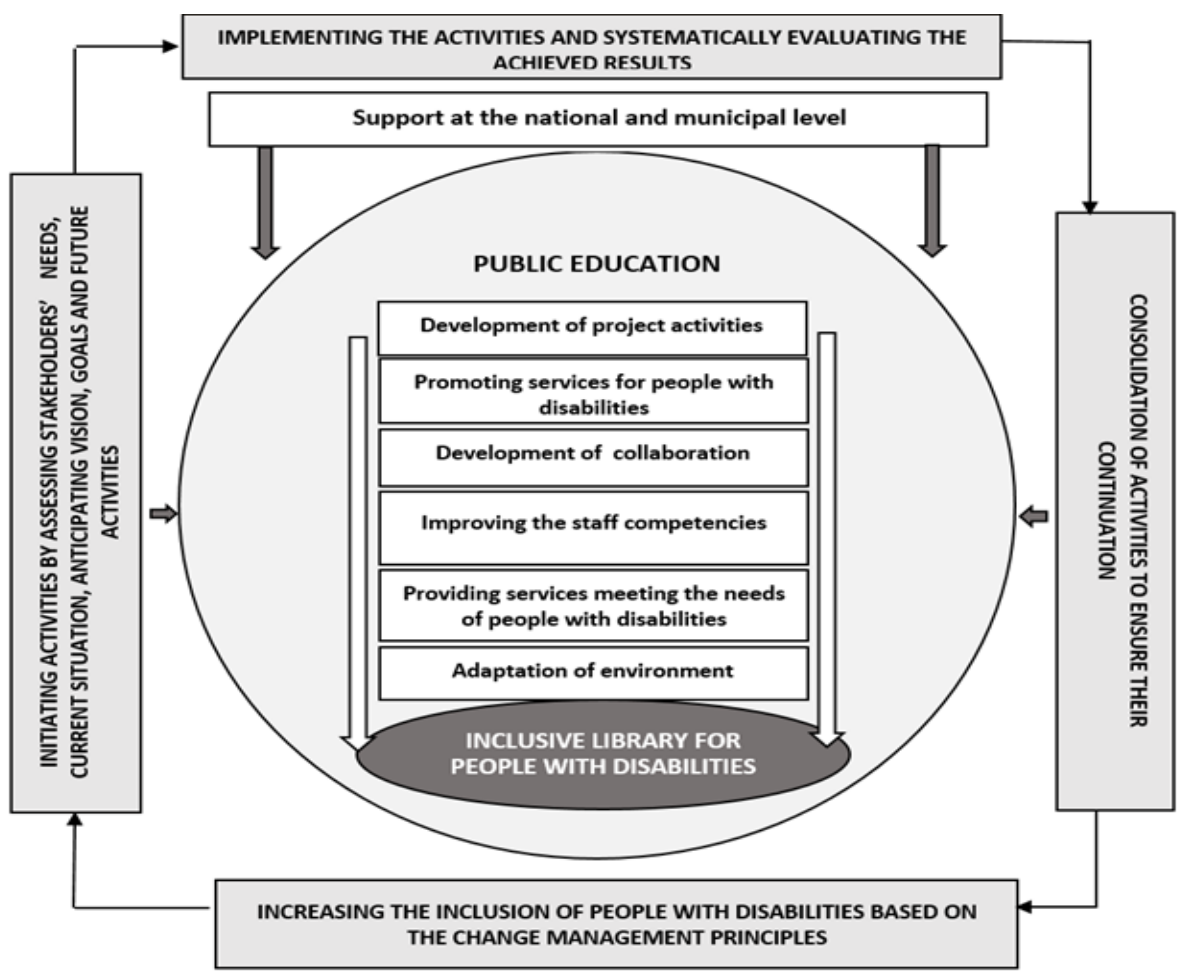

Figure 4.1. Model of an inclusive library for people with disabilities. Adapted from: Improving the Quality of Library Services for Students with Disabilities (p. 61) by A. Gibson, 2006, Westport, CT: Libraries Unlimited; The Theory and Practice of Change Management (p. 14) by J. Hayes, 2010, Basingstoke, Palgrave Macmillan; "Public Libraries and Access for Children with Disabilities and Their Families: A Proposed Inclusive Library Model", by J. Kaeding, D. L, Velasquez and D. Price, 2017, Journal of the Australian Library and Information Association, 66, p. 13; empirical research data.

Figure 4.1 shows that the change management in the organization is an essential component of the model of an inclusive library for people with disabilities. Aiming to increase the inclusion of people with disabilities and implement related changes, libraries should take into consideration the key stages of change management: to initiate changes related to services for people with disabilities, substantiate their needs, foresee vision and goals of change, design plans for implementing changes, appoint appropriate staff, and provide an internal communication system. Then it is necessary to implement the changes: the planned activities are conducted, monitoring is 
performed, interim and final results are evaluated. Finally, changes are consolidated, ensuring their further implementation: activities related to services for people with disabilities become a part of the library culture (Bold, 2011, p. 872; Hayes, 2010, p. 14; Jalgat, 2015, pp. 1234-1235; Kaeding, 2015, p. 23; Kaunda \& Chizwina, 2019, p. 17). The assessment of the needs of people with disabilities and organizations representing them and their involvement in planning, designing, implementing and evaluating the services are of particular importance in this process. However, the research revealed that in most libraries of Šiauliai and Telšiai counties the inclusion of people with disabilities and their representatives in the development and evaluation of library services is insufficient, as well as the surveys on the opinion of people with disabilities are not conducted ("we do not conduct surveys for people with disabilities"). It should be noted that the inclusion of people with disabilities in planning, designing, implementing and evaluating the services as well as conducting research of their needs, more emphasis was placed on the inclusion of people with disabilities in formulating the activities and objectives of libraries to better respond to their needs.

Another component of the model in the context of Lithuania is political support at the national and local (municipal) level. This research showed that individuals representing people with disabilities often miss the legal commitment of libraries to increase the inclusion of people with disabilities, greater funding for adapting library infrastructure and meeting the cultural needs of people with disabilities. Heads of libraries miss clearer legal regulation for the inclusion of people with disabilities and their participation in cultural life, research on the needs of people with disabilities at the national and local level, greater funding for adapting library environment, purchasing of information resources, and development of staff competencies. By designing an inclusive library as an organizational change, already initially, local governments would be involved in the process of planning the change, activities and resources necessary for its implementation. Planning to implement this change by all public regional libraries, it would be necessary to require greater national support.

\subsection{The practical implementation of the theoretical model of an inclusive library for people with disabilities}

It has already been mentioned that empirical research has confirmed the significance of all components and features highlighted in the theoretical model. Further, we will present the aspects that we have found in each part of the model in the case of Lithuanian libraries. The research revealed that access of people with disabilities to libraries is often limited by both objective (disability nature, inadequate library infrastructure, a lack of information about library services) and subjective (negative public attitude, a lack of motivation of people with disabilities, a lack of competencies of library staff, the discrepancy between library events and the needs of people with disabilities) factors. One of the ways to overcome these obstacles is to increase the inclusion of libraries by improving the library environment, services, staff competencies, developing 
cooperation between organizations for people with disabilities and libraries, publicizing information on library services, organizing public education events, etc.

In the area of adaptation of environment, the research showed that the infrastructure and technological equipment of the libraries of Šiauliai and Telšiai counties are insufficiently adapted to people with disabilities, but people with physical disability ("buildings are completely unsuitable for people with orthopaedic impairment", "there are no lifts, there are narrow aisles between shelves") and people with visual disability ("there is a lack of accompanying people", "library stairs and doors should be marked with contrasting bright labels") face this problem the most. This problem is particularly pronounced in libraries in smaller regions, where accessibility to libraries for people with disabilities is restricted not only by the inadequacy of library infrastructure but also by external factors ("people living in smaller towns or villages have difficulty to move due to lack of funds and buses"). A lack of technological equipment is most commonly encountered by visually-impaired people who miss text magnification equipment, audio links, hearing-impaired people miss hearing aids, events are not translated into sign language ("there are no audio links", "there are no text magnifiers", "library events are not translated into sign language"). People with physical disabilities cannot watch events remotely, order books ("events are not broadcast live", "books cannot be pre-ordered"). In this area, there is a need to improve virtual library services by enabling online bookings and live broadcasts of events.

Library services for people with disabilities include the compliance of information resources and events with the needs of people with disabilities. The research revealed that the supply and availability of information resources in many libraries in Šiauliai and Telšiai counties is sufficient and meets the needs of people with disabilities. It should be noted that it is essential for libraries to have information resources adapted to people with different disabilities. However, the research revealed that visually impaired people miss audiobooks, books with larger fonts, e-books ("there are no books and other publications are recorded", "more books could be in pdf format"), and people with mental disabilities miss books with adapted content ("people with mental disability need books with simple content, books for colouring, knitting"). According to heads of libraries, to meet the needs of people with disabilities, libraries purchase new publications, borrow books from other libraries (e.g. Lithuanian Library for the Blind), and provide remote delivery of books. However, updating the funds of books is limited by poor availability of publications for people with disabilities at the national level. The research found that people with physical disabilities face the most difficulties to reach information resources: they are unsatisfied with the current situation of book delivery because libraries do not provide access to books for relatives of people with disabilities ("books are not lent them to be delivered to another person"), and information about this service is insufficiently publicized ("there is no information about this service"). In the area of event organization, it was revealed that all events offered by libraries - informational, cultural, and educational activities ("exhibitions of works, educational activities, meetings", "poetry 
evenings, concerts", "reading aloud", "lectures on health, movie screenings") - are relevant for people with disabilities. However, in this area not only a variety of events but also access to them is important: events can be held in libraries or spaces convenient for people with disabilities, broadcast remotely, and translated into sign language.

In the area of staff competencies, the research showed that library staff is helpful but they lack sufficient competence of disability cognition and tolerance ("employees are very poorly prepared", "they do not understand people with disabilities", "they see people with disabilities as different people"). Statements by heads of libraries that staff, according to their abilities, develop their competencies in various events, projects, share best practices with other libraries ("we promote our staff to attend conferences, training, seminars", "we design projects", "we take over experience from other libraries") do not yet demonstrate learning to work with the audience with specific needs. Interviewees revealed that organizations representing people with disabilities would agree to contribute to the development of library staff competencies ("we could advise on staff training, choosing topics", "we could organize joint training").

In the area of cooperation between organizations for people with disabilities and libraries of Šiauliai and Telšiai counties it was found that the main areas where cooperation is ongoing could be developed in future are joint events, educational, cultural and project activities ("joint events are ongoing", "we organise exhibitions, educational activities", "we conduct projects including digital literacy"). It should be noted that heads of organizations for people with disabilities are willing to be involved in the planning and designing of services ("social workers could contribute more to educational, therapeutic activities", "we could organize activities together"), and the measures to develop this cooperation could include the organization of meetings, discussions and the development and implementation of joint activities.

In the area of publicity about services, there was a controversial perception of the adequacy of information on library services for people with disabilities ("information is completely sufficient", "information is completely insufficient"). Representatives of people with disabilities usually find the necessary information on social networks, library websites, learn about it from library staff or receive it by email. The same means of information were mentioned by heads of libraries. It should be noted that the most relevant information for people with disabilities is about library events, new books, and educational activities. Access to information for people with disabilities would be enhanced by information regularly sent via email to organizations for people with disabilities about upcoming events, educational activities, etc., and in this way, the inclusion of organizations representing people with disabilities would be promoted.

The research conducted in Lithuania actualized two other relevant components in designing an inclusive library for people with disabilities - public education and development of project activities. Public education has always been and is one of the missions of the library, but in this 
case, we consider broader public education on the socialization of people with disabilities. According to interviewees, "by organizing such campaigns and events, the public would learn more about the needs of people with disabilities", "there would be more opportunities to see similarities rather than differences." It should be emphasized that these events can have a significant impact on reducing the stigmatisation of disability by broadening the boundaries between public awareness and cognition of disability. Projects, as a management technique to implement innovation, are at the same time state-supported activities to absorb EU funds to modernize the public sector, including the supply of the most modern technology ("we purchase new equipment during projects"), to provide new services ("project activities include people with disabilities who participate in training, workshops"), and to develop staff competencies ("we train staff to implement international qualification projects"). On the other hand, it is an opportunity to cooperate intensively with the organizations interested in the result, take over the best practices of other countries as well as to achieve, analyse, evaluate and publicize the intended outcomes within the stipulated time.

\section{Discussion}

The services provided for people with disabilities is not a new activity of libraries, however, the changing needs of society require a new approach to this group of stakeholders and the appropriate development of services. Increasing the inclusion of people with disabilities is not a common organizational change, but it is close to the implementation of innovation, as a diversity of disabilities is growing, the needs of socialized individuals, and public expectations for access to services are growing as well. According to Likar \& Fatur (2013, pp. 59-60), the implementation of innovations involves the searching, selecting, and implementing new activities and ideas, and the results of this process can lead to new services or new organizational activities. Designing an inclusive library for people with disabilities changes the organization itself, its culture and the services it provides, which become more accessible and responsive to the needs of different members of society. It is, therefore, difficult to manage the process of creating an inclusive organization for people with disabilities. This research revealed that the creation of a socially inclusive library as the change management covers the essential stages - initiating, implementing, and consolidating changes related to library services for people with disabilities. In order to become organizations for people with disabilities, libraries have to initiate the necessary changes by justifying their needs, researching the environment, evaluating ongoing and planning future activities, setting out the goals for changes and the measures needed to implement them. Later, libraries have to implement the changes, to evaluate the achieved results, and to ensure further implementation of the activities (Jalagat, 2015, p. 1235; Kaunda \& Chizwina, 2019, p. 17; KennettHensel \& Payne, 2018, p. 24). In this way, innovative activities and services related to the enhancement of social inclusion are introduced in the activities of libraries and the library culture is changing as well. Likar \& Fatur (2013, p. 59) and Perryman \& Jeng (2019, pp. 104-105) argue 
that innovation focuses on problem-solving and activity development. Meanwhile, the implementation of innovation is primarily related to the potential benefits to social stakeholders, so it is important to assess the needs of the environment and stakeholders. Aiming to perform this, libraries should actively involve them in the planning, designing, and implementing the library services. Therefore, the development of an inclusive library focuses on the consistent involvement of representatives of people with disabilities in the change management through the development process: starting with the assessment of the needs of people with disabilities, taking into account a diversity of disabilities, then involving organizations representing people with disabilities in the planning, designing, and implementing the services.

\section{Conclusion}

This research has revealed that the relevance of an inclusive library can be based on the changing needs of society and library stakeholders, who also determine the role of libraries in emphasizing the importance of the social role. The implementation of the social role promotes the development of the library as an inclusive organization. An inclusive library creates added value for society by contributing to the implementation of social justice and promoting the inclusion of persons belonging to socially excluded groups, including people with disabilities.

Increasing the inclusion of people with disabilities is related to the implementation of changes and innovations, as the documents regulating the activities of libraries only recommend to increase their social role, but do not propose specific models suitable for Lithuanian libraries, leaving it to the libraries themselves. Therefore, the change management, including initiating change, anticipating change goals, activities and intended outcomes, selecting appropriate interventions and factors enabling change, implementing planned activities, monitoring interim results, assessing outcomes, and consolidating change, are important for the development of an inclusive library. The assessment of the needs of people with disabilities and organizations representing them, and their involvement in the planning, designing, implementing, and evaluating the services, are of particular importance.

According to the empirical research, the social inclusion of libraries in Šiauliai and Telšiai counties in the area of services for people with disabilities can be increased by institutionalizing the model of an inclusive library for people with disabilities proposed in this research. The research revealed the importance of systematic analysis of the needs of people with disabilities in the organizational change management and their involvement in planning, designing, implementing the services as well as monitoring and evaluating the activities. In the area of adaptation of environment, the consistent upgrading of infrastructure and technological equipment, the development of distant (e.g. delivery of books to convenient places for people with disabilities) and virtual (e.g. live broadcast of events) services are important. In the area of improving the quality of services for people with disabilities, the consistency of library information resources and events with the needs 
of people with disabilities is important, with a focus on regular updating of the funds of books, delivery of books to places convenient for people with disabilities, and the use of e-books. The research showed that people with disabilities are interested in various events held in libraries. However, it is very important to ensure access to events and to enable people with disabilities to participate in these events both directly and watch them in the distance way. In the area of development of staff competencies, continuous development of staff competencies as well as cooperation between organizations for people with disabilities and libraries in organizing staff training is important. In the area of cooperation development, libraries need to develop cooperation with organizations for people with disabilities by involving them in the planning, designing, implementing, and evaluating the services, and by holding more meetings and discussions. In the area of promotion of services, accessibility to information for people with disabilities could be increased by information sent by email to organizations for people with disabilities about library events. In the Lithuanian context, additional components of the model of an inclusive library for people with disabilities were highlighted, such as political support at the national and local (municipal) level as well as the development of project activities and public education.

The empirical research was conducted in two counties of Lithuania (Šiauliai and Telšiai). Because budget-based libraries in Lithuania have a similar governance structure, operate according to the same documents, and have similar possibilities provided by the Government and Ministry of Culture to address social issues, the empirical findings presented in this research can be applied at the national level, except for the capital region, which should be investigated separately due to the

high concentration of specialized libraries and the National Library. It would also be useful to analyse the best practices of other European countries whose libraries have made the biggest progress in promoting social inclusion.

\section{References}

1. Adkins, D., \& Bushman, B. (2015). A Special Needs Approach A Study of How Libraries Can Start Programs for Children with Disabilities. Children and Libraries, 28-33.

2. Appleton, L., Hall, H., Duff, S. A., \& Raeside, R. (2018). UK Public Library Roles and Value: A Focus Group Analysis. Journal of Librarianship and Information Science, 50(3), 275-283. doi.org/10.1177/0961000618769987

3. Ballantyne, H. (2018). An Introduction to Change Management Theory for Veterinary Nurses: Part Two. Veterinary Nursing Journal, 33(12), 332-335. doi: 10.1080/17415349.2018.1523697

4. Bhatt, R. (2017). Theoretical Perspective of Change Management. International Journal of Research and Commerce Management, 8(2), 34-36. ISSN 0976-2183

5. Bold, O. (2011). A Perspective on Organizational Change Issue - Case Study on the Application of Two Change Models. Review of International Comparative Management, 12(5), 871-882.

6. Butt, F. S., Nawab, S., \& Zahid, M. (2018). Organizational Factors and Individual Effectiveness: Moderating Role of Change Management. Journal of Psychological Research, 33(1), 75-100. 
Maj / May 2020, leto / year 5, številka / number 2, str. / pp. 79-101.

7. Casselden, B., Pickard, A. J., \& McLeod, J. (2015). The Challenges Facing Public Libraries in the Big Society: The Role of Volunteers, and the Issues That Surround Their Use in England. Journal of Librarianship and Information Science, 47(3), 187-203.doi: 10.1177/0961000613518820.

8. Chaputula, A. H., \& Mapulanga, P. M. (2017). Provision of Library Services to People with Disabilities in Malawi. South African Journal of Library and Information Science, 82(2), 1-10.

9. Dangi, T. B., \& Gribb, W. J. (2018). Sustainable Ecotourism Management and Visitor Experiences: Managing Conflicting Perspectives in Rocky Mountain National Park, USA. Journal of Ecotourism, 17(3), 338-358. doi: 10.1080/14724049.2018.1502250

10. Davey, A. (2013). The Library of the Future: A Response to Envisioning the Library of the Future by Arts Council. Retrieved from https://www.artscouncil.org.uk/sites/default/files/download file/The library_of_the_future_May_2013.pdf.

11. Delaney, G., \& Bates J. (2015). Envisioning the Academic Library: A Reflection on Roles, Relevancy and Relationships. New Review of Academic Librarianship, 21, 30-51. doi: 10.1080/13614533.2014.911194

12. Gibson, A. (2006). Disability Support Services, Victoria University of Wellington. In Improving the Quality of Library Services for Students with Disabilities, 57-66. Westport, CT: Libraries Unlimited.

13. Harrison, J. S., Freeman, R. E., \& Sá de Abreu, M. C. (2015). Stakeholder Theory as an Ethical Approach to Effective Management: Applying the Theory to Multiple Contexts. Review Bussiness management, 17(55), 858-869.

14. Hawkins, J. E. (2018). The Practical Utility and Suitability of Email Interviews in Qualitative Research. The Qualitative Report, 23(2), 493-501.

15. Hayes, J. (2010). The Theory and Practice of Change Management. Basingstoke. Palgrave Macmillan.

16. Irwin, B., \& Silk, K. (2019). Changing Stakeholder Expectations of Library Value. Public Library Quarterly, 38(3), 320-330.

17. Jalagat, R. C. (2015). The Impact of Change and Change Management in Achieving Corporate Goals and Objectives: Organizational Perspective. International Journal of Science and Research, 5(11), 1233-1239. doi: 10.21275/ART20163105

18. Johnson, C. (2012). How do Public Libraries Create Social Capital? An Analysis of Interactions between Library Staff and Patrons. Library and Information Science Research, 34, 52-62.

19. Juchnevič, L. (2016). Šiuolaikiniai bibliotekos konceptai tinklaveikos visuomenëje: kontekstas ir požiūriai. Informacijos mokslai, 74, 95-114.

20. Juchnevič, L. (2015). Biblioteku vaidmenu kaita tinklaveikos visuomeneje: Lietuvos atvejis. Daktaro disertacija. Vilniaus universitetas.

21. Kaeding, J., Velasquez, D. L., \& Price, D. (2017). Public Libraries and Access for Children with Disabilities and Their Families: A Proposed Inclusive Library Model. Journal of the Australian Library and Information Association, 66 (2), 96-115.

22. Kaeding, J. (2015). Opening Access to Public Libraries for Children with Special Needs \& their Families. Retrieved from https://www.education.sa.gov.au/sites/default/files/opening_access_to_publ ic_libraries_for_children_with_special_needs_and_their_families_online.pdf?acsf_files_redirect.

23. Kaunda, N., \& Chizwina, S. (2019). Providing Access to Students with Print Disabilities: The Case of the North-West University in South Africa. Journal of Access Services, 16(1), 6-20. doi: 10.1080/15367967.2018.1547641

24. Kennett-Hensel, P. A., \& Payne, D. M. (2018). Guiding Principles for Ethical Change Management. Journal of Business and Management, 24(2), 19-45. doi: 10.6347/JBM.201809.24(2).0002

25. Kijauskaitè, G., \& Alèbaitè, I. (2016). Projekto "Bibliotekos pažangai 2" dalyvių tyrimas. Retrieved from http://3erdve.lt/media/public/Tyrimai_2016/bp2_kokyb_projektu_dalyviai_v2.pdf.

26. Koh, D. (2019). Music Catalog for Blind and Visually Impaired Patrons. Music Reference Services Quarterly, 22(1-2), 30-41. doi: 10.1080/10588167.2019.1583494

27. Koller, D., Le Pouesard, M., \& Rummens, J. A. (2018). Defining Social Inclusion for Children with Disabilities: A Critical Literature Review. Children \& society, 32, 1-13. 
Maj / May 2020, leto / year 5, številka / number 2, str. / pp. 79-101.

28. Kowalsky, M., \& Woodruff, J. (2017). Creating Inclusive Library Environments: a Planning Guide for Serving Patrons with Disabilities. Chicago: ALA Editions, an imprint of the American Library Association.

29. Kulikauskienè, K. (2019). Socialiai įtraukios bibliotekos samprata besikeičiančioje visuomenèje. Socialiniai tyrimai, 42(1), 67-78.

30. Lawrence, P. (2015). Leading Change - Insights Into How Leaders Actually Approach the Challenge of Complexity. Journal of Change Management, 15(3), 231-252. doi: 10.1080/14697017.2015.1021271

31. Likar, B., \& Fatur, P. (2013). Innovation Management. Retrieved from https://www.researchgate.n et/publication/292127499_Innovation_management.

32. Lipiński, R., \& Jamro, K. (2018). Information Flow Model: a Versatile and Effective Change Management Model. Proceedings of the International Conference on Intellectual Capital, 253-259.

33. Lloyd, P. (2019). The Public Library as a Protective Factor: An Introduction to Library Social Work. Public Library Quarterly, 38(1), 1-14.

34. Lokman, I. M. (2006). E-Mail Interviewing in Qualitative Research: a Methodological Discussion. Journal of the American Society for Information Science and Technology, 57(10), 1284 - 1295. doi: 10.1002/asi.20416.

35. Moisey, S. D. (2007). The Inclusive Libraries Initiative: Enhancing the Access of Persons with Developmental Disabilities to Information and Communication Technology. The Developmental Disabilities Bulletin, 35(1-2), 56-71.

36. Mulliken, A. (2017).There is Nothing Inherently Mysterious about Assistive Technology. A Qualitative Study about Blind User Experiences in US Academic Libraries. Reference \& User Services Quarterly, 57(2), 115-126.

37. Pečeliūnaitè, A. (2018). Bibliotekų veiklos ir bendruomenès narių gyvenimo kokybès sąsajos: nepriklausomas Lietuvos apskričių viešųų bibliotekų tyrimas. Kultūra ir visuomenè, 9(2), 61-87.

38. Perryman, C. L., \& Jeng, L. H. (2019). Changing Models of Library Education to Benefit Rural Communities. Public Library Quarterly, 39(2), 102-114. doi: 10.1080/01616846.2019.1621736

39. Pionke, J. J. (2017). Toward Holistic Accessibility Narratives from Functionally Diverse Patrons. Reference \& User Services Quarterly, 57(1), 48-56.

40. Pressley, T. (2017). Public Libraries, Serious Mental Illness, and Homelessness: A Survey of Public Librarians. Public Library Quarterly, 36(1), 61-76. doi: 10.1080/01616846.2017.1275772

41. Racelis, A. (2018). Library Services for the Poor: Theoretical Framework for Library Social Responsibility. Pedagogical Research, 3(2), 1-9. Retrieved from https://doi.org/10.20897/pr/90831.

42. Reid, P. H. (2019). How Good is Our Public Library Service? The Evolution of a New Quality Standards Framework for Scottish Public Libraries 2012-2017. Journal of Librarianship and Information Science, 1 -12. Retrieved from https://doi.org/10.1177/0961000619855430.

43. Ruškus, J. (2002). Negales fenomenas. Monografija. Šiauliai, ŠUL.

44. Strover, S. (2019). Public Libraries and 21st Century Digital Equity Goals. Communication Research and Practice, 5(2), 188-205.

45. Subramaniam, M., Kodama, C., \& Oxley, R. (2013). School Librarians as Ambassadors of Inclusive Information Access for Students with Disabilities. School library research, 16, 1-34. ISSN: 21651019

46. Sung, H. Y., Hepworth, M., \& Ragsdell, G. (2012). Investigating Essential Elements of Community Engagement in Public Libraries: An Exploratory Qualitative Study. Journal of Librarianship and Information Science, 45(3), 206-218. doi: 10.1177/0961000612448205

47. Talmaciu, I. (2014). Comparative Analysis of Different Models of Organizational Change. Valahian Journal of Economic Studies, 5(19), 77-86.

48. Valaitytè, A. (2018). Edukacinè veikla bibliotekoje = edukaciniai renginiai? Šiandien aktualu, 58(1), 173-181.

49. Vimarlund, V., \& Manzoora, M. (2017). E-services for the Social Inclusion of People with Disabilities: A Literature Review. Technology and Disability, 29, 15-33. doi: 10.3233/TAD-170175 
Maj / May 2020, leto / year 5, številka / number 2, str. / pp. 79-101.

50. Wyatt, D., Mcquire, S., \& Butt, D. (2018). Libraries as Redistributive Technology: From Capacity to Culture in Queensland's Public Library Network. New media \& society, 20(8), 2934-2953. Retrieved from https://doi.org/10.1177/1461444817738235.

51. Yilmaz, B., \& Cevher, N. (2015). Future of Public Libraries: Opinions of Public Librarians in Turkey. International Federation of Library Associations and Institutions, 41(4), 336-352. doi: $10.1177 / 0340035215608861$

52. Young, D. W. (2018). Creating Inclusive Library Environments: A Planning Guide for Serving Patrons with Disabilities. Technical Services Quarterly, 35(1), 131-132. doi: 10.1080/07317131.201 7.1385311

$* * *$

Kristina Kulikauskienė, MA, graduate of Public Administration programme in Šiauliai University (Lithuania), researcher at Šiauliai county public library. Scientific interests: change management in public organizations, creation of inclusive organizations, good governance.

$* * *$

Laima Liukinevičienė, Professor Dr. at Siauliai University, Institute of Regional Development (since 1996). Scientific interests: leadership in public sector, change management, good governance at municipal level.

$* * *$

Povzetek:

\section{Teoretični model inkluzivne knjižnice za invalide in njeno praktično izvajanje}

Namen in izvirnost: Cilj te študije je analizirati koncept inkluzivne in družbeno odgovorne knjižnice, razviti teoretični model vključujoče knjižnice za invalide in raziskati praktične možnosti za izvajanje tega modela $\mathrm{v}$ regionalnih knjižnicah, da bi zmanjšali socialno izključenost invalidov in povečati njihove socialne vključenosti. $\mathrm{V}$ prispevku so predstavljeni rezultati empiričnih raziskav, izvedenih $\mathrm{v}$ dveh okrožjih Litve. Na podlagi rezultatov razgovorov vodij knjižnic in vodij organizacij, ki predstavljajo invalide, je bil dopolnjen model vključujoče knjižnice in aktualizirano upravljanje sprememb vključujoče knjižnice.

Metoda: Metode te študije temeljijo na teoriji deležnikov (Dangi \& Gribb, 2018, str. 339-341; Harrison, Freeman in Abreu, 2015, str. 859-860; Lipiński in Jamro, 2018, str. 225), kadar upravljanje deležnikov vključuje zadovoljevanje njihovih potreb in zagotavljanje njihovega dobrega počutja. Teoretični del raziskave uporablja metode analize, posploševanja in sistematizacije znanstvene literature, ki so omogočile teoretično opredelitev koncepta inkluzivne javne knjižnice za invalide, utemeljile instrument empiričnega raziskovanja in razpravo o rezultatih empirične raziskave. $\mathrm{V}$ empiričnem delu je bila za izvedbo javnomnenjske raziskave organizacij, ki predstavljajo invalide in vodje knjižnic izbrana kvalitativna metoda intervjujev po e-pošti. Dobljene rezultate smo analizirali, nato pa teoretični model inkluzivne knjižnice dopolnili s praktičnimi spoznanji empirične raziskave.

Rezultati: Rezultati raziskave so pokazali, da spreminjajoči se odnos javnosti do javnih storitev in njihove dostopnosti (pričakovana je večja dostopnost in raznolikost) določa spremembo vlog knjižnic, ki temeljijo na proračunu, in predpogoj za razvoj vključujoče knjižnice za invalide. Na podlagi teoretičnih in empiričnih ugotovitev, pridobljenih med raziskavo, je bil razvit in utemeljen model vključujoče knjižnice za invalide. Dokazano je bilo tudi, da razvoj vključujoče knjižnice za invalide zahteva upravljanje sprememb, ki vključuje vse zainteresirane strani, tj. predstavnike invalidov in institucije, ki izvajajo javno politiko na nacionalni in lokalni ravni, $\mathrm{v}$ vse faze procesa preoblikovanja $\mathrm{v}$ postanejo vključujoča organizacija za invalide.

Družba: Ta študija poudarja potrebo po povečanju socialne vključenosti knjižnic, da bi zadovoljili potrebe vseh zainteresiranih strani, tudi invalidov. Povečanje socialne vključenosti knjižnic lahko 
Izzivi prihodnosti / Challenges of the Future,

Maj / May 2020, leto / year 5, številka / number 2, str. / pp. 79-101.

zmanjša socialno izključenost invalidov in na splošno spodbudi njihovo vključevanje v skupnost in družbo. Inkluzivna knjižnica ustvarja za družbo dodano vrednost in prispeva $\mathrm{k}$ izvajanju socialne pravičnosti.

Omejitve / nadaljnje raziskave: Empirična raziskava je bila izvedena v dveh okrožjih Litve (Šiauliai in Telšiai), v kateri je sodelovalo 10 knjižnic. Ker imajo v Litvi knjižnice podobno upravljavsko strukturo, delujejo na podlagi enakih strateških dokumentov Republike Litve, imajo podobne možnosti, ki jih zagotavljata vlada in ministrstvo za kulturo, da se vključijo v inovativne dejavnosti in rešijo socialne težave. Rezultate empirične raziskave je mogoče uporabiti na nacionalni ravni, razen za prestolnico, ki jo je treba preučiti ločeno, zaradi visoke koncentracije specializiranih knjižnic in nacionalne knjižnice. Koristno bi bilo tudi analizirati najboljše prakse drugih evropskih držav, katerih knjižnice so dosegle največji napredek pri spodbujanju socialne vključenosti.

Ključne besede: socialna vključenost, model inkluzivne knjižnice za invalide, knjižnične storitve za invalide.

Copyright (c) 2020 Kristina KULIKAUSKIENĖ, Laima LIUKINEVIČIENĖ

\section{(c) (†) ()}

Creative Commons License

This work is licensed under a Creative Commons Attribution-ShareAlike 4.0 International License. 